\title{
Digital Communication: Priorities in the Relationship of Principal Leadership and Collaborative Community at Malaysian School
}

\author{
Mat Rahimi Yusof ${ }^{1, *}$, Dayang Rafidah Syariff M. Fuad ${ }^{2}$, \\ Mohd Faiz Mohd Yaakob', Yahya Don ${ }^{1}$, Ibrahim ${ }^{3}$ \\ ${ }^{1}$ School of Education and Modern Languages, Universiti Utara Malaysia,Kedah, Malaysia \\ ${ }^{2}$ Faculty of Management and Economics, Universiti Pendidikan Sultan Idris, Perak,Malaysia \\ ${ }^{3}$ Department of Teacher Training Education, Serambi Mekah University Acheh, Indonesia
}

Received December 19, 2019; Revised March 2, 2020; Accepted March 12, 2020

Copyright $(\mathrm{C} 2020$ by authors, all rights reserved. Authors agree that this article remains permanently open access under the terms of the Creative Commons Attribution License 4.0 International License

\begin{abstract}
The impact of the development of the Industrial Revolution 4.0 (IR 4.0) also involved the communication element. This new medium of communication has taken its place recently in the most community to create a virtual community. Therefore, this quantitative study of 202 respondents was carried out to identify the contribution of this new medium of digital communication in the relationship between principal leadership and collaborative community in schools. The data were collected through the questionnaire and analysed using AMOS software version 22. It was found that principal's leadership contributed significantly to digital communication $(\beta=.073, \mathrm{CR}=6.393, \mathrm{P}=.000)$, the new medium of digital communication also contributed significantly to the collaborative community $(\beta=.149, \mathrm{CR}=7.787, \mathrm{P}=.000)$, and its' also contributed as a mediator between principals leadership and community at schools. These findings indicate that the relationship between school principals and collaborative community can be enhanced by the use of a new medium of digital communication such as WhatsApp, Telegram and any other methods. Through this study, a model of collaborative community measurement was developed. This model can be used as a guidance for all the principals to apply this medium in school and also provides a clear signal for the school leaders to achieve the ninth shift of Malaysia Education Blueprint (PPPM 2013-2025) that is a collaboration with parents, communities and the private sector as a whole.
\end{abstract}

Keywords Educational Leadership, Principal Leadership, Digital Communication

\section{Introduction}

The breakthrough of technological communication in the era of industrial revolution 4.0 has resulted in the emergency of digital communication in our daily life. This rapid development has created a virtual community among cyber citizens worldwide (Polizzi, Ofem, Coyle, Lundquist \& Rushton, 2019). This digital communication has dominated the process of disseminating and communicating pieces of information, ideas and emotions or skills from one individual to another and also from one place to another place among the cyber citizens. It also served as a connecting link to the elements existed in one's organisations (Dominick, 2013; Hoy \& Miskel, 2013; James \& Figaro-henry, 2017).

In Malaysia, according to the statistics released by the Communications and Multimedia Commission (MCMC) in 2018, there were 24.6 millions users of social networking apps (MCMC, 2018). This phenomenon also impacted educators. The use of digital communication as a medium to communicate in school started to grow. A survey conducted on 352 Malaysian secondary school teachers showed $336(95.5 \%)$ users of communication applications such as WhatsApp, Telegram, Viber, and Wechat; 296 (84.1\%) users of other social networking such as Twitter, Facebook and Instagram (Yusof, 2017).

Based on the statistics released by MCMC (2018) and the findings of the recent researchers, it showed that the new medium of virtual communication is expanding. This development provides an opportunity for school leaders to integrate this new medium of communication into school's leadership practices. However, to what extent does the new medium of communication play a role in the relationship between the principal school leadership and 
collaborative community in schools?

\section{Literature Review}

In Malaysia, collaborative community and school collaboration are not new to the education system. The history of collaborative community and school collaboration has existed before Malaysia independence day in 1957. It started from the Razak Statement (1956) until the existence of the enactment of Education Act (1966), the collaborative community continue to be emphasised in every educational agenda (Mohammed Sani et al., 2013; Siti Aliah, Muhamad Suhaimai, \& Jamaluddin, 2016).

After the Malaysia independence day, the collaboration between school and community has never ceased. Community collaboration in school continues to be taken seriously by the Malaysia government as it is included in the Malaysia Educational Development Plan (PPPM 2013-2025) as the ninth shift, which is to work closely with parents, communities and the private sector (MOE, 2013).

The emphasis on community collaboration in schools is important because school is a social institution that connects all social units in the community such as parents, alumni, institutions of higher learning, the private sectors and local authorities. Therefore, the collaboration between schools and community needs to be emphasised by all parties, especially school leaders, to improve the relationships and enhance the educational effectiveness (Aziah Ismail \& Abdullah, 2013; Mattar et al., 2013; Sheldon, 2015).

Many studies emphasising the parent involvement in schools by researchers over the past decade concluded that changes in schools are as the result of the collaboration between schools and community that involved directly in the educational process (Coutts, Sheridan, Kwon, \& Semke, 2012; Paezah \& Faridah, 2017; Simon, 2017). The previous study also showed that collaborative community at schools could improve academic achievement, a variety of learning experiences, presence, emotions, personality, create a safer environment, improve parenting skills and encourage community collaboration (Gross et al., 2015).

Therefore, to enhance the relationship between school and community, besides the effectiveness of school leaders, the elements of communication need to be strengthened. School leaders need to seize this opportunity to apply this new medium of communication as an effort to reach out to the community and build a meaningful relationship between the schools and the community. This medium provides school leaders with an opportunity to communicate with community wirelessly regardless of the time and geographically location (Yusof, Mohd Faiz, \& Ibrahim, 2019).

\section{Problem Statement}

Although a literature review has shown that collaborative outcomes between schools, communities and parent involvement are beneficial to both parties, the reality of the study suggested that the aspect of community involvement in schools is still weak and not entirely achieved (Mohammed Sani \& Jamalul Lail, 2012; Siti Aliah et al., 2016). According to this study, the community is less likely to involve in the Parent Teacher Association (PIBG) activities. The parents believed that their children's education are the school's responsibilities, they do not understand the collaboration concept and the advantages it can bring to them and the school (Mohammed Sani, Ibrahim Saedah \& Norlidah, 2014). Additionally, research showed that some schools placed their priorities to the school wholely without realising the importance of community role in schools. They failed to see the importance of this community's role in helping with the improvement of academic excellence and school effectiveness (Epstein \& Sanders, 2006; Mohammed Sani, Ibrahim Saedah \& Norlidah, 2014).

The importance of collaborative interest between schools and communities on school effectiveness and student achievement had made this study proposed so that school leaders should integrate this new medium of communication in their leadership. In this study, the new medium of digital communication was defined as the integration of mobile devices, applications or social networks in communicating messages or information from the sender to the recipients. The definition of a new medium of digital communication in the context of the relationship between school and community is how this new digital communication medium acts as a catalyst for a new form of effective communication. Thus, it deems necessary for the researcher to develop a model for the collaborative community in education based on the national educational environment and requirements.

Based on the literature review, issues and concerns, hypothesis models in figure 1 proposed for testing. 


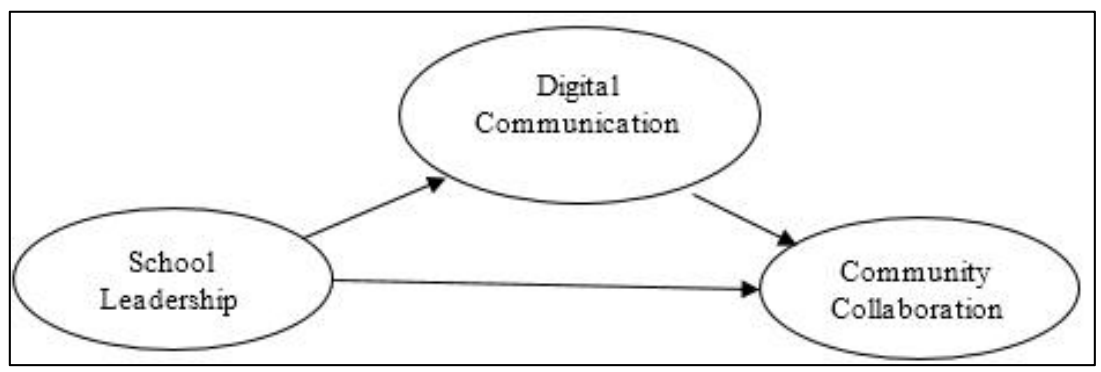

Figure 1. The hypothesis of the Research Models

Based on figure 1, the school leaders' leadership is reflective of the five proposed indicators, that is the role of school leaders in community engagement in schools. The new medium, which is digital communication as a mediator variable, is closely linked to the use of technologies in digital communications. These new technologies such as smartphones and its software applications (such as WhatsApp and so on) play a central role in the relationship between school and community. The community collaboration was represented by four constructs, namely volunteerism, home learning, smart collaboration and parental involvement - all variables represented by 32 indicators.

\section{Purpose of the Study}

The purpose of this study is to identify the role of the new medium of digital communication in the relationship between school leadership and community collaboration. This study also tested the mediating role of this new medium in communication between school leadership and community collaboration in schools.

\section{Research Methodology}

This quantitative study used a cross-sectional study design (Airasian, Gay, \& Mills, 2011; Lodico, T., Dean, Spaulding, \& Voegtle, 2010). The study sample size consisted of 202 respondents (Male $=67$; Female 135). The sample was selected randomly among teachers, parents, PIBG committees and ALUMNI. The data collection of this study was collected using a modified questionnaire from the Parent Involvement Practices (Epstein, 1986). The structural Equation Model (SEM), AMOS version 22, was used to analyse the data collected.

To identify the role of digital communication in the relationship between school leadership and community collaboration, the value of regression coefficients and critical ratio (C.R) is observed. If the value of C.R is higher than 1.96, and the significant value is less than or equal to 0.05 , the finding shows that the predictor variable significantly predicts the independent variables. In determining the effect of the mediator variable on the interaction between the independent variable and the dependent variable, total effect value, direct effect and indirect effect values are observed. If the value of the indirect impact is less than or equal to the total effect, the findings show that the mediator variable affects the relationship between the predictor variables and independent variables.

Next, the fit of the hypothesized model was validated using the fit indices $\chi^{2}$ (CMIN), CFI, RMSEA, PCFI dan PNFI. The hypothesized models correspond to the study data where the chi-square values $=>0.05, \mathrm{CFI}=>0.90$ $(0.80-0.89$ accepted), RMSEA $>0.08$ (accepted if $<0.1)$ (Alan Bryman, 1989), PNFI and PCFI $>0.5$ (Meyers, Gamst, \& Guarino, 2013).

\section{Findings and Discussion}

Table 1 showed the descriptive findings' normality, convergence validity, composite reliability and correlation between leadership variables (LS), new communication medium (CM) and the impact of collaborative community variables represented by four constructs namely smart collaboration (CL), home learning (BR), volunteerism (SR), and parenting (IB). Findings showed that all variables reached convergent validity (AVE> 0.5), composite reliability $(\mathrm{CR}>0.701)$, discriminant validity (square-root AVE $>$ correlation values between variables) and data normality (skewness and kurtosis values between -1 and +1 ). Findings also showed that all variables have a strong correlation with each other.

To address the objectives of the study, Table 2 represents the critical ratio (C.R) contributions for each variable in principal leadership to the digital and collaborative community, and also the contribution of the digital communication to the collaborative community. The findings indicate that the principal leadership contributed significantly to the digital communication $(\beta=.149, C . R=7.787, P=.000$ ), while principal leadership did not contribute significantly to community collaboration $(\beta=.053, \mathrm{C} . \mathrm{R}=.450, \mathrm{P}=.652)$. This finding suggests that there are still some weaknesses in the relationship between principal leadership and collaborative community in schools. 
Table 1. Descriptive Analysis

\begin{tabular}{|c|c|c|c|c|c|c|c|c|c|c|c|c|}
\hline & Mean & sp & Skew & kurt & AVE & CR & 1 & 2 & 3 & 4 & 5 & 6 \\
\hline 1 LS & 3.993 & 0.056 & -0.55 & -0.23 & 0.55 & 0.83 & $\mathbf{0 . 7 4}$ & & & & & \\
\hline 2 CM & 3.936 & 0.057 & -0.28 & -0.25 & 0.53 & 0.85 & 0.66 & $\mathbf{0 . 7 4}$ & & & & \\
\hline 3 CL & 3.933 & 0.056 & -0.33 & -0.24 & 0.62 & 0.89 & 0.55 & 0.81 & $\mathbf{0 . 7 9}$ & & & \\
\hline 4 BR & 4.112 & 0.05 & -0.32 & -0.52 & 0.5 & 0.79 & 0.52 & 0.77 & 0.67 & $\mathbf{0 . 7 1}$ & & \\
\hline 5 SR & 4.177 & 0.044 & -0.17 & -0.51 & 0.59 & 0.85 & 0.29 & 0.43 & 0.37 & 0.35 & $\mathbf{0 . 7 6}$ & \\
\hline 6 IB & 3.666 & 0.507 & -0.16 & -0.24 & 0.73 & 0.91 & 0.47 & 0.7 & 0.61 & 0.58 & 0.32 & $\mathbf{0 . 8 5}$ \\
\hline
\end{tabular}

Note: SQRT AVE value (bold) shown in prints.

Table 2. Regression coefficient

\begin{tabular}{|c|c|c|c|c|c|c|c|}
\hline & & & Estimate & S.E. & C.R. & P & Result \\
\hline Digital communication & $<--$ & School leadership & .465 & .073 & 6.393 & $* * *$ & Significant \\
\hline Community collaborative & $<---$ & Digital communication & 1.158 & .149 & 7.787 & $* * *$ & Significant \\
\hline Community collaborative & $<---$ & School leadership & .024 & .053 & .450 & .652 & Not significant \\
\hline
\end{tabular}

Table 3. The effects of mediator variables in the model.

\begin{tabular}{|c|c|c|c|c|c|c|c|c|c|}
\hline & \multicolumn{3}{|c|}{ Full effect } & \multicolumn{3}{c|}{ Direct effect } & \multicolumn{3}{c|}{ Indirect effect } \\
\hline & LS & CM & KK & LS & CM & KK & LS & CM & KK \\
\hline CM & 0.465 & 0 & 0 & 0.47 & 0 & 0 & 0 & 0 & 0 \\
\hline KK & 0.562 & 1.16 & 0 & 0.02 & 1.16 & 0 & 0.54 & 0 & 0 \\
\hline
\end{tabular}

Indicator: LS: Principal Leadership, KK: Collaborative Community, CM: Digital Communication

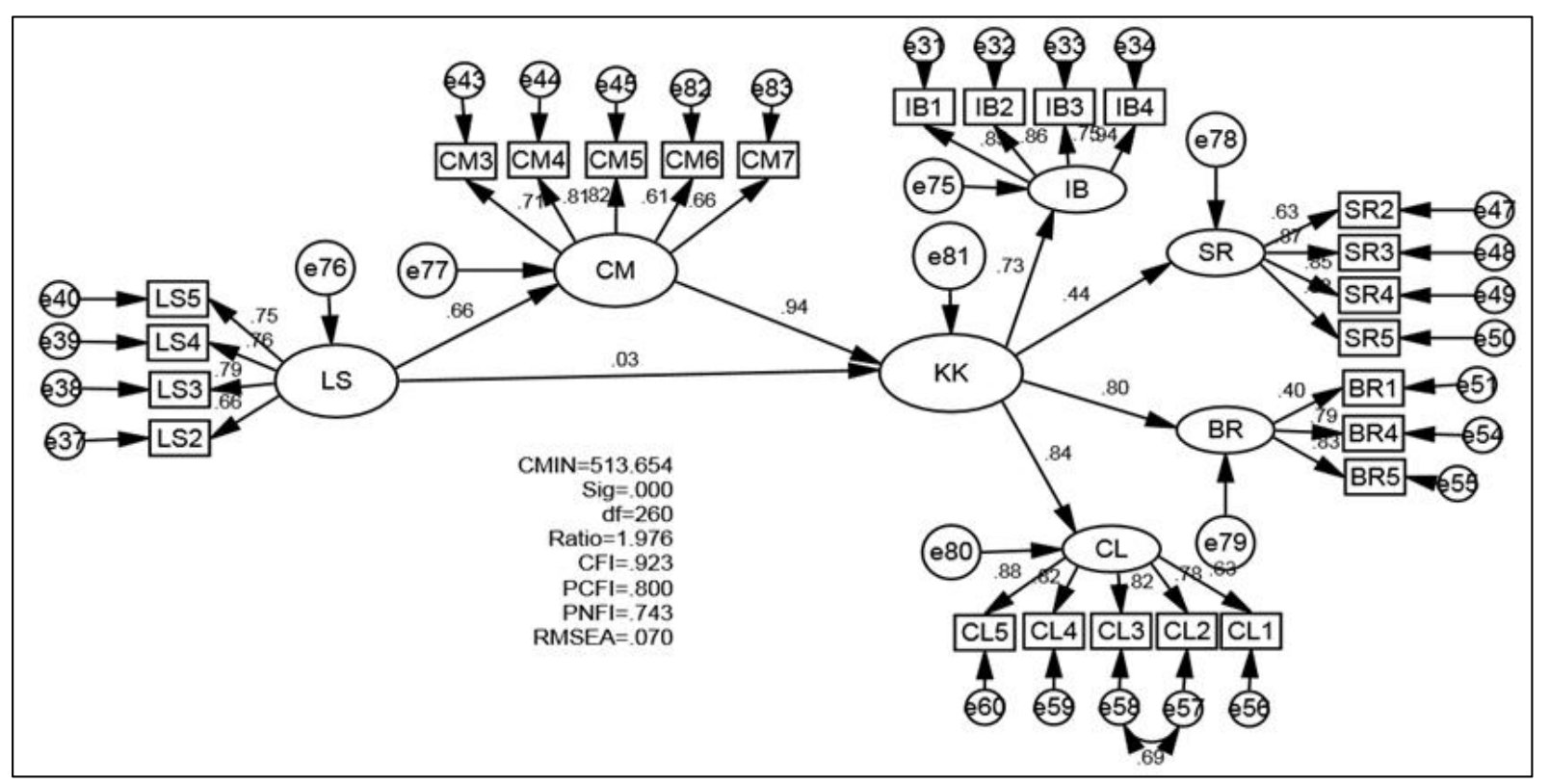

Figure 2. Measurement of collaborative community model in secondary schools

Meanwhile, the following table 3 shows the value of total effect, indirect effect and direct effect. The results showed that the full effect value (0.562) is higher than the direct effect value $(0.540)$. These findings conclude that digital communication acts as a mediator variable in the relationship between principal leadership and community collaboration in secondary schools at coastal Terengganu, Malaysia. This finding also implies that the principals practically influence the community collaborations in schools. However, this relationship will be enhanced if a new medium of communication (digital communication) such as WhatsApp, Telegrams, Facebook and various digital communication mediums was applied through the interactions of the principals towards the community.

Figure 2 shows the leadership model, the new medium of communication and the collaboration community result 
in secondary schools at coastal Terengganu. The findings conclude that the study data is in line with the developed model $\quad(\mathrm{CFI}=.923 ; \quad$ PCFI $=.800, \quad$ PNFI $=.743$; RMSEA $=.070)$.

\section{Conclusions}

The study conducting on 202 respondents aimed to identify the contribution of the new medium of communication in the relationship between the principal leadership and community collaboration in secondary schools in Malaysia. The findings of this study concluded that the new medium of communication acts as a mediating variable that contributes significantly to improve the relationship between principal's leadership and community collaboration in schools.

Next, the findings indicate that the principal's leadership could empower these new mediums of communication, especially among parents, communities and stakeholders had a significant impact on the collaborative community at schools. In other words, the relationship between schools and communities developed through the introduction of new communication practices that used digital technologies such as smartphones, tablets, iPads and many more. The finding of this study also succeeded in developing a community-based collaborative measurement model at secondary schools in Malaysia.

The finding of this study in line with the study over the past decade found that changes in schools are as the result of the collaboration between schools and community that involved directly in the educational process. The previous study also showed that collaborative community at schools could improve academic achievement, a variety of learning experiences, presence, emotions, personality, create a safer environment, improve parenting skills and encourage collaboratitve community (Coutts, Sheridan, Kwon, \& Semke, 2012; Paezah \& Faridah, 2017; Simon, 2017; Gross et al., 2015).

Therefore, based on the results of this study, hopefully the stakeholders and the parties involved in collaborative between school and community will be able to understand, practice, and pay attention to strengthen the discussed dimensions in the effort to nurture the relationship between school and community. In Malaysia educational education context, school leaders should strive to make the ninth shift in the Malaysia Education Blueprint Plan 2013-2025 become a reality through collaboration with parents, communities and the private sectors.

Finally, the constructs in collaborative community models can serve as a guide for principals to integrate this new medium of communication in their leadership practices. Nevertheless, this study suggests that a more comprehensive review should be taken by future researchers to further strengthen this community's collaborative models in other areas of education.

\section{REFERENCES}

[1] Airasian, P. W., Gay, L. R., \& Mills, G. E. (2011). Educational Research: Competencies for Analysis and Applications (10th Edition). Upple Sadder River: NJ: Pearson Education.

[2] Alan Bryman. (1989). Research Methods and Organization Studies. London: Routledge.

[3] Aziah Ismail, \& Abdullah, A. G. K. (2013). Parents' involvement in Malaysian autonomous schools. International Journal of Asian Social Science, 3(3), $657-668$.

[4] Coutts, M. J., Sheridan, S. M., Kwon, K., \& Semke, C. (2012). The Effect of Teacher's Invitations to Parental Involvement on Children's Externalizing Problem Behaviors: An Examination of a CBC Intervention. In Nebraska Center for Research on Children, Youth, Families and Schools.CYFS Working Paper 2012-3.

[5] Dominick, J. R. (2013). The dynamics of mass communication (Twelfth Edi). New York: Mc Graw Hill.

[6] Epstein, J. L. (1986). Parents' Reactions to Teacher Practices of Parent Involvement. The Elementary School Journal, 86(3), 277. https://doi.org/10.1086/461449

[7] Epstein, J. L., \& Sanders, M. G. (2006). Prospect for Change: Preparing Educators for School, Family and Community Partnerships. Peabody Journal of Education, 81(2), 81-120.

[8] Gross, J. M. S., Haines, S. ., Hill, C., G.L, F., Blue-Manning, M., \& Turnbull, A. P. (2015). 2015. Strong School-Community Partnerships in Inclusive Schools Are "Part of The Fabric of the School....We Count to Them. School Community Journal, 25(2), 9-34.

[9] Hoy, W. K., \& Miskel, C. G. (2013). Educational administration (Ninth Edit). New York: Mc Graw Hill Higher Education.

[10] James, F., \& Figaro-henry, S. (2017). Building collective leadership capacity using collaborative twenty-first century digital tools. School Leadership \& Management, 0(0), 1-17. https://doi.org/10.1080/13632434.2017.1367277

[11] Lodico, M. G., T., Dean, Spaulding, \& Voegtle, K. H. (2010). Methods in educational research from theory to practice (Second ed). San Francisco: Jossey - Bass.

[12] Mattar, D., Pansiri, N. O., Heck, R. H., Shatzer, R. H., Caldarella, P., Hallam, P. R., ... Mokhele, M. L. (2013). Principals' Instructional Leadership and School Performance: Implications for Policy Development. Journal of Educational Administration, 48, 130-141.https://doi.org/10.1177/1094670509353043

[13] Meyers, L. S., Gamst, G., \& Guarino, A. J. (2013). Applied multivariate research: Design and interpretation. (Second Edi). London: Sage Publication.

[14] Ministry of Education. (2013). Malaysia Education Blueprint 2013 - 2025. Putrajaya: Ministry of Education. 
[15] Mohammed Sani, Ibrahim Saedah, S., \& Norlidah, A. (2014). Pengurusan Kerja Rumah yang Efektif. Kuala Lumpur: Penerbit Universiti Malaya.

[16] Mohammed Sani, I., Ahmad Zabidi, A. R., Husaina Banu, K., Mohd Sani, I., Ahmad Zabidi, Abdul Razak, Husaina Banu, K., Mohammed Sani, I., ... Ahmad Zabidi, Abdul Razak, Husaina Banu, K. (2013). Smart Principals and Smart Schools. 13th International Educational Technology Conference, 103(826-836) 826-836.https://doi.org/10.1016/j.sbspro.2013.10.404

[17] Mohammed Sani, I., \& Jamalul Lail, A. W. (2012). Kepimpinan Pendidikan. Bangi: Penerbit UKM.

[18] Paezah, A. H., \& Faridah, Y. (2017). Kepentingan Penglibatan Ibu Bapa Dalam Aktiviti Pembelajaran Kanak-kanak di Prasekolah. Perseidangan Antarabangsa Sains Sosial Dan Kemanusiaan.

[19] Polizzi, S. J., Ofem, B., Coyle, W., Lundquist, K., \& Rushton, G. T. (2019). The use of visual network scales in teacher leader development. Teaching and Teacher Education, 83 $42-53$. https://doi.org/10.1016/j.tate.2019.03.018

[20] Sheldon, S. (2015). Moving beyond monitoring: A District LeadershipApproach to School, Family, and Community Partnerships. In Family school partnership in context. Springer International Publishing.

[21] Simon, S. (2017). A Study of Primary School Parents' Interaction with Teachers' in Malaysia. International Journal of Educational and Pedagogical Sciences, 11(2), 354-361.

[22] Siti Aliah, I., Muhamad Suhaimai, T., \& Jamaluddin, M. A. (2016). Permuafakatan sekolah dengan komuniti dalam pendidikan: Peranan kepimpinan transformasional dan komunikasi pengetua. International Confrence on Possttgraduate Research 2016, (December), 382-401.

[23] Yusof, M. R. (2017). Pembinaan model kepimpinan instruksional maya, pola komunikasi dan kompetensi pengajaran guru sekolah menengah di Malaysia. Universiti Malaysia Terengganu.

[24] Yusof, M. R., Mohd Faiz, M. Y., \& Ibrahim, M. Y. (2019). Digital leadership among school leaders in Malaysia. International Journal of Innovative Technology and Exploring Engineering, 8(9), 1481-1485. 